\title{
宮古島近海に抒ける固有地震活動
}

\author{
沖縄気象台* 溜 㴊 功 史 \\ 気像庁地震火山部** 山田安之・石垣祐三十・高木康 伸 ${ }^{\ddagger}$ \\ 気象大学校林* 中 村 雅 基 \\ 気象研究所**** 前田憲二・岡田正実
}

\section{Characteristic Earthquake Sequences near Miyakojima Island, Ryukyu Arc, Japan}

\author{
Koji TAMARIBUChI \\ Okinawa Meteorological Observatory, Japan Meteorological Agency, Higawa 1-15-15, \\ Naha 900-8517, Japan \\ Yasuyuki Yamada, Yuzo IshigakI ${ }^{\dagger}$, and Yasunobu TAKAGI ${ }^{\ddagger}$ \\ Seismological and Volcanological Department, Japan Meteorological Agency, \\ Ohte-machi 1-3-4, Chiyoda-ku, Tokyo 100-8122, Japan \\ Masaki NAKAMURA ${ }^{\#}$ \\ Meteorological College, Japan Meteorological Agency, \\ Asahi-cho 7-4-81, Kashiwa 277-0852, Japan

\section{Kenji Maeda and Masami Okada} \\ Meteorological Research Institute, Nagamine 1-1, Tsukuba 305-0052, Japan \\ (Received August 27, 2009; Accepted December 24, 2009)
}

We found eight M5.1 characteristic earthquakes regularly occurring since 1966 on the plate boundary between the Eurasian plate and the Philippine Sea plate near Miyakojima Island, the Ryukyu Arc, Japan. The quake recurrence interval was 5.89 years in average, and the standard deviation was only 0.73 years. The accumulating stress presumably ruptured the same asperity enclosed by the creeping zone repeatedly. Also, we found three other groups of small repeating earthquakes of $M 4$, which occurred close to the hypocenters of the $M 5$ events. Those groups also occurred regularly and we can consider them to be 'characteristic' earthquake sequences. Now, we called those groups A, B, and C. It is not clear whether groups A and B had an intrinsic recurrence interval or if they influenced each other. However, two events of group $\mathrm{C}$ occurred within one week after the $M 5$ quakes, indicating that the $M 5$ events triggered the group C events whose asperity had sufficient strain energy. No earthquake exceeding $M 7$, which could change the recurrence intervals, has been observed on the subduction zone around the Ryukyu Islands. Therefore, there should be

\footnotetext{
* $=900-8517$ 那覇市樋川 1-15-15

** $=$ 100-8122 東京都千代田区大手町 1-3-4

*** $=277-0852$ 柏市旭町 7-4-81

**** 个305-0052 つくば市長峰 1-1
}

†現所属：横浜地方気象台 =231-0862 横浜市中区 山手町 99

‡現所属：内閣府（防災担当）干100-8969 東京都千 代田区霞が関 1-2-2

\# 現所属: 気象庁地震火山部 $\boldsymbol{\top}$ 100-8122 東京都千 代田区大手町 1-3-4 
numerous characteristic earthquake sequences in other areas of the Ryukyu district. We expect that the next $M 5$ earthquake at $50 \mathrm{~km}$ depth on the plate boundary near Miyakojima Island will occur between September 2012 and July 2014 with 70\% probability, using the small-sample theory with a log-normal distribution model. Moreover, the $M 5$ event may be accompanied by an $M 4$ quake that could rupture the asperity of group C within one week.

Key words: Characteristic earthquake, Repeating earthquake, Asperity, Waveform similarity, Ryukyu Arc

\section{§1. はじめに}

固有地震 (characteristic earthquake) モデルは,「特 定の断層で発生する最大規模の地震は, ほぼ同じ大きさ の地震が繰り返し発生する.」として, Schwartz and Coppersmith (1984)によって提案された. 彼らのモデ ルには, 繰り返し間隔に関する規則性は取り入れられて いない。しかし，一般に固有地震モデルとは，「特定の断 層で発生する最大規模の地震は, ほぼ同じ大きさ, ほぼ 同じ繰り返し間隔で発生する.」[例えば，五十嵐 (2002)あのとして広く受け入れられている.さらに, 固有地震の概念を説明する際には, Gutenberg-Richter の式に従わない性質があることや, 複数のアスペリティ を同時に破壊するか否かなど破壊過程の類似性に言及す る場合もある. 本稿では,「ほぼ同じ大きさ，ほぼ同じ繰 り返し間隔で, ほぼ同じ領域を破壊する地震」を固有地 震と呼ぶことにする.

固有地震と類似した言葉として, 繰り返し地震 $(r e-$ current earthquake) や相似地震 (repeating earthquake) が用いられている. 繰り返し地震は, 特定のアス ペリティが繰り返し破壊することにより発生する地震を 示し, 繰り返し間隔には言及しない。 また, 相似地震は, 同一観測点において波形が相似である地震を指し，一般 に, 波形の相関係数がある閾值を超える観測点の数が基 準数以上となる地震として定義される [例えば, Igarashi et al. (2003)]. このように, 相似地震を検出すること は固有地震や繰り返し地震を検出するための手段にも なっている.これらの関係をべン図で示すと Fig. 1 のよ うになる。ここで，相似地震と繰り返し地震が一致しな いのは，上記相似地震を検出するための閾值が不適切な ため, 繰り返し地震でないものを相似地震とみなした り, 特定のアスペリティを破壊している繰り返し地震で あるにあかかわらず，破壊過程が異なるために相似地震 之検出されなかったりする場合があるためである.

地震調查研究推進本部地震調査委員会は, 全国を対象 とした活断層調査等に基づいて, 将来発生する大規模な 地震の長期評価を行っている. その際, 固有地震モデル に準拠した更新過程モデルまたは時間予測モデル [Shimazaki and Nakata (1980)] を用いている. しかし，大
規模地震の発生間隔は長く, 知られている過去の事例が 少ない場合む多いため, 平均発生間隔やばらつきの程度 について必ずしも十分な精度で求められているとはいえ ない, 一方, 中小規模の固有地震は発生間隔が比較的短 く, 多くのサンプルを得ることができるため, 固有地震 モデルを評価するうえで重要な役割を果たすと考えられ る.

これまで, 小規模な固有地震の活動についていくつか 議論されてきた. Nadeau and Johnson (1998) はアメリ カ合衆国カリフォルニア州のサンアンドレアス断層で見 つかっている微小固有地震活動から, 地震モーメントと すべり量などの断層パラメー夕の関係式を提案した。

Matsuzawa et al. (2002) は, 岩手県釜石沖で $M 4.8$ 程度 の固有地震活動を見いだし, プレート境界の安定すべり 域に囲まれたアスペリティの存在を示すとと屯に次の固 有地震の発生確率を示した. Uchida et al. (2005) は, 上 記釜石沖に扮ける固有地震活動の発生間隔のゆらぎにつ いて，より小さなイベントの後では発生間隔が長くなる ことや, 周囲でスロースリップが発生することによって 発生間隔が短くなることを指摘した。 また, Uchida et al. (2007) は, 上記釜石沖に抢ける固有地震の空間的な 大きさや応力降下量を解析するとと屯に, 周辺で発生す る微小地震を精査することによりアスペリティの階層構 造について言及した. 長谷川・他 (2005) は, 東北地方を

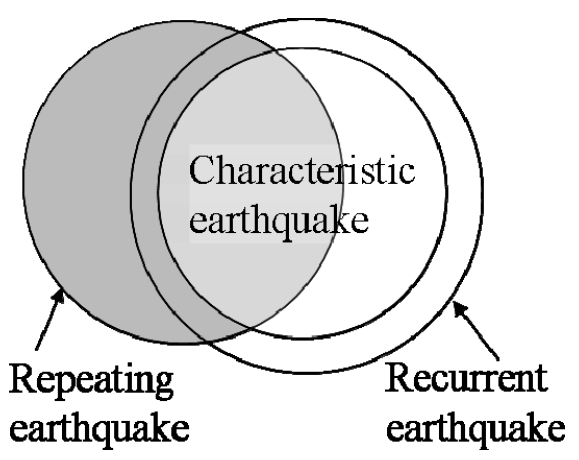

Fig. 1. Venn diagram for concept of characteristic earthquake, recurrent earthquake, and repeating earthquake. 
対象に, 地震カタログを精査して, 中小規模の固有地震 の候補を多数抽出した. しかし, 日本国内の他地方と比 較して観測網, データが極端に限定されている琉球弧で は，これまでほとんど調査されておらず，とりわけ宮古 島近海では全く調査されていない.

一方, 繰り返し地震や相似地震についてもさまざまな 研究がなされている. Igarashi et al. (2003) は, 同一観 測点に拈ける波形の相似性を用いて小繰り返し地震を抽 出した. Uchida et al. (2003) や Uchida et al. (2004), Matsubara et al. (2005) は大地震の余震域に抢いて小繰 り返し地震を解析し，プレート境界のスロースリップを 見いだした. Chen et al. (2007) は, カリフォルニア州 パークフィールド, 台湾東部, 東北日本で発生する繰り 返し地震を用いて，プレートの沈み込み速度を考慮し， 地震モーメントと繰り返し間隔の関係式を提案した。 Yamawaki et al. (2004) は東北地方の太平洋プレートの 沈み込み帯で発生した相似地震群を用いて, 岩手山にお いて顕著な火山活動や $M 6$ クラスの地震が発生した時 期に, 地殼構造に変化があったことを示した. Schaff and Beroza (2004) は, 相似地震を用いて, 1989 年に発 生したロマ・プリエー夕地震と 1984 年に発生したモル ガンヒル地震の発生による実体波速度の微小な変化を検 出した。このように, 繰り返し地震や相似地震は地震学 や火山学のさまざまな分野で多く利用されている.

琉球弧は, 九州南部から台湾にかけて約 $1300 \mathrm{~km}$ に わたり弓なりに連なる島弧である (Fig. 2).この島弧の 南東沖では, ユーラシアプレートの下にフィリピン海プ レートが琉球海溝から約 6 7 cm/yr の速さで沈み込ん でおり [Seno et al. (1993)], それに伴う地震活動が見ら れる. 他方, 島弧の北西沖では, 沖縄トラフが約 $5 \mathrm{~cm} /$ $\mathrm{yr}$ の速さで拡大しているため, 琉球弧の南西部に扮け るフィリピン海プレートとユーラシアプレート間の相対 速度は約 $12.5 \mathrm{~cm} / \mathrm{yr}$ に達すると考えられている [Heki and Kataoka (2008)].

琉球弧之同様にフィリピン海プレートが沈み込んでい る駿河トラフ, 南海トラフでは, 東海, 東南海, 南海地 震といった $M 8$ クラスのプレート境界地震が知られて いる. また, 宮崎県東方沖の日向灘でも $M 7$ クラスのプ レート境界地震が知られている. 台湾東部を除く琉球弧 では, 1900 年以降の気象庁カタログ (Fig. 2(a)) による と, $M 7.5$ 以上の地震は 1901 年の奄美大島近海の地震 (M 7.5) や 1911 年の奄美大島近海の地震 $(M 8.0)$ などが 発生している。しかし, いずれも観測網が十分に整備さ れる以前の地震であったために, プレート境界で発生し た地震か否かは判断できない. 少なくとも最近 30 年間 では, $M 7$ を超えるプレート境界地震は発生しておら
ず, 琉球弧におけるプレート境界の固着状況はほとんど わかっていない，一方，M4〜M5 クラスのプレート境 界地震は石垣島近海から宮古島近海などで多く発生して おり, 固有地震活動が含まれている可能性がある。特に, 宮古島近海では, 1997 年 6 月 19 日に宮古島近海で発 生した $M 5.1$ の地震で, 宮古島で震度 4 を観測するな ど, $M 5$ クラスの地震活動も時折発生している活発な活 動領域であるため, 固有地震活動が発生している可能性 がある.また, 地震計が島嶼部の中では比較的密に配置 されているため, 調査を行いやすい.

そこで本稿では, 国内外の地震力夕ログを用いて, 宮 古島近海に打ける地震活動を精查し, 波形の相似性を確 認することによって, 固有地震活動を検出し, その特徵 を調查した. 琉球弧で固有地震活動を調査することは, 琉球弧におけるプレート境界の固着状況やプレート運動 を解明する手がかりとなるほか, 将来的に固有地震モデ ルの検証に資するものである.

\section{§2. データおよび解析手法}

本稿では宮古島近海 $\left(24.5^{\circ} \mathrm{N} \sim 25.0^{\circ} \mathrm{N}, 125.0^{\circ} \mathrm{E} \sim\right.$ $125.5^{\circ} \mathrm{E}$ ) におけるプレート境界（大まかな深さとして は 40〜60 km) の地震を対象とする (Fig. 2(c)). 波形の 相似性をできるだけ長い期間で確認するために， 3 通り の方法で調查, 解析を行った.

第一に, 1964 年から 2008 年までの気象庁カタログ, および 1964 年から 2006 年までの ISC カタログから, $M 5$ 以上の地震について試行錯䛊的に $\mathrm{M}-\mathrm{T}$ 図の調査を 行った。ほぼ同じ時間間隔で発生しているほぼ同規模の 地震群について宮古島 (MIYAKJ), 石垣島 (ISHIGA), お よび那覇 (NAHA) 観測点の, 59 型地震波形（ドラム式 100 倍变位型地震計）の記象紙扮よび 95 型震度計（加 速度型強震計）のデジタル波形を収集して, 目視によっ て変位波形の相似性を確認した。 その際, 95 型震度計の データは 59 型の特性に変換した。なお， 1997 年以前の 気象庁カタログは島嶼部の震源精度が悪いため, 主に ISC カタログを用いた. また, MIYAKJ では 1971 年に 59 型地震計を設置したため, 1971 年以前については ISHIGA と NAHA のみで調査を行った。

第二に, $M 4$ 程度の相似地震を確認するために, 1997 年から 2008 年までの $M 4$ 以上の地震について, 宮古島 2 (MIYKJ2), 沖縄城辺 (OKIGUS), 池間臨時 (IKEMA), および多良間島 (TARAMA) の 4 観測点 (Fig. 2(c)) の高 感度地震計による速度波形（UD 成分）を用いて, 1 3 $\mathrm{Hz}$ の帯域で P 相の 0.5 秒前から 40 秒間程度の波形の コヒーレンスを計算し相似性を評価した。 相似地震のグ ループに分類する際, 波形が存在するすべての観測点で 

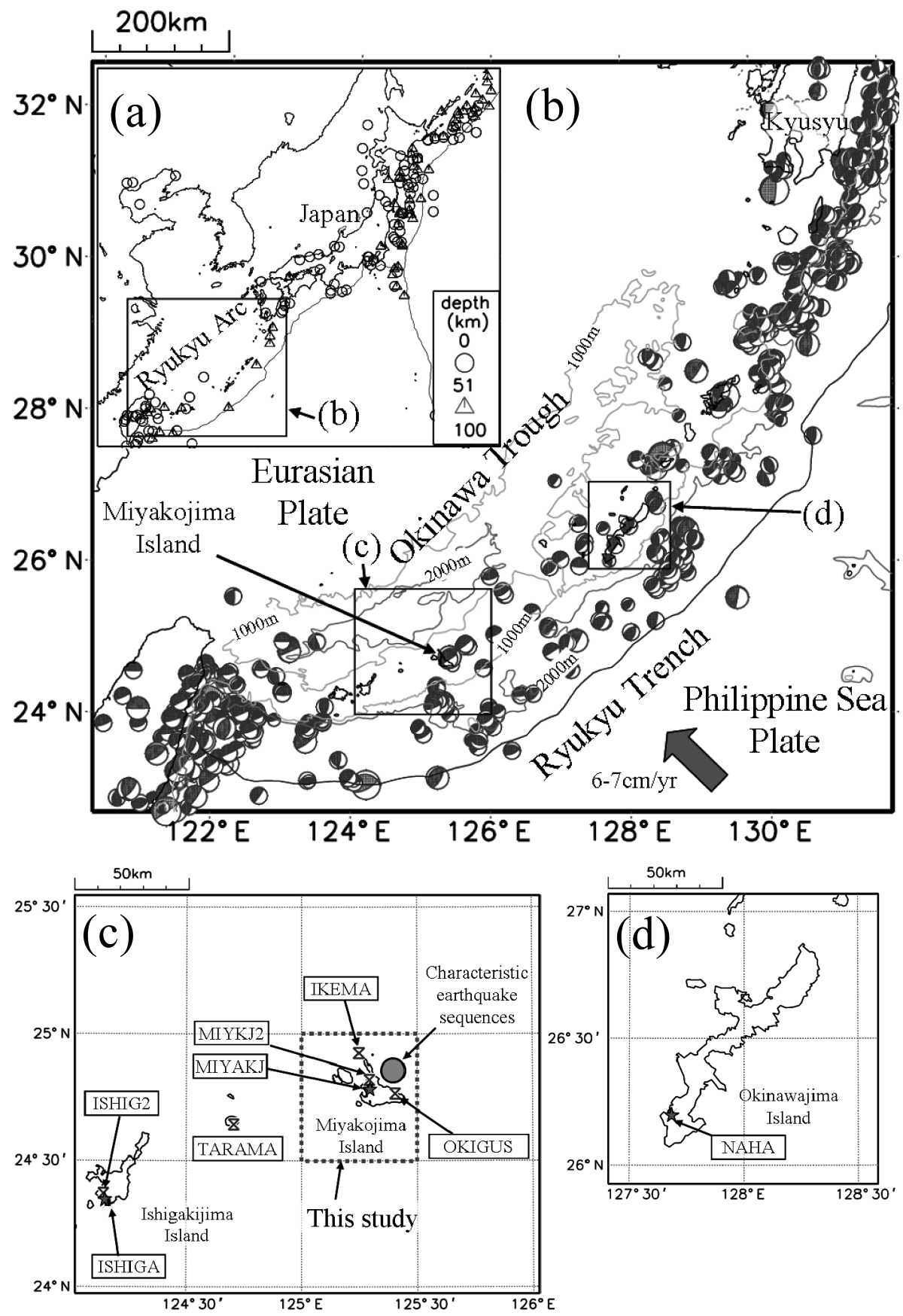

$\mathbf{Z}$ : The high sensitive seismometers

市: The 59-type seismograph, the 95-type seismograph

Fig. 2. (a) Seismic activity over M 7.0 in and around Japan from 1900 to 2008 (by JMA) (b) Tectonic setting around the Ryukyu Arc and site indexes. Moment tensor solutions of the thrust earthquakes (P axis: $65^{\circ} \leqq$ azimuth $\leqq 200^{\circ}$, plunge $\leqq 45^{\circ}$, T axis: plunge $\geqq 45^{\circ}, \mathrm{N}$ axis: plunge $\leqq 30^{\circ}$ ), determined by the F-net project, are also plotted. (c, d) Locations of the seismometers on and near Miyakojima Island. 


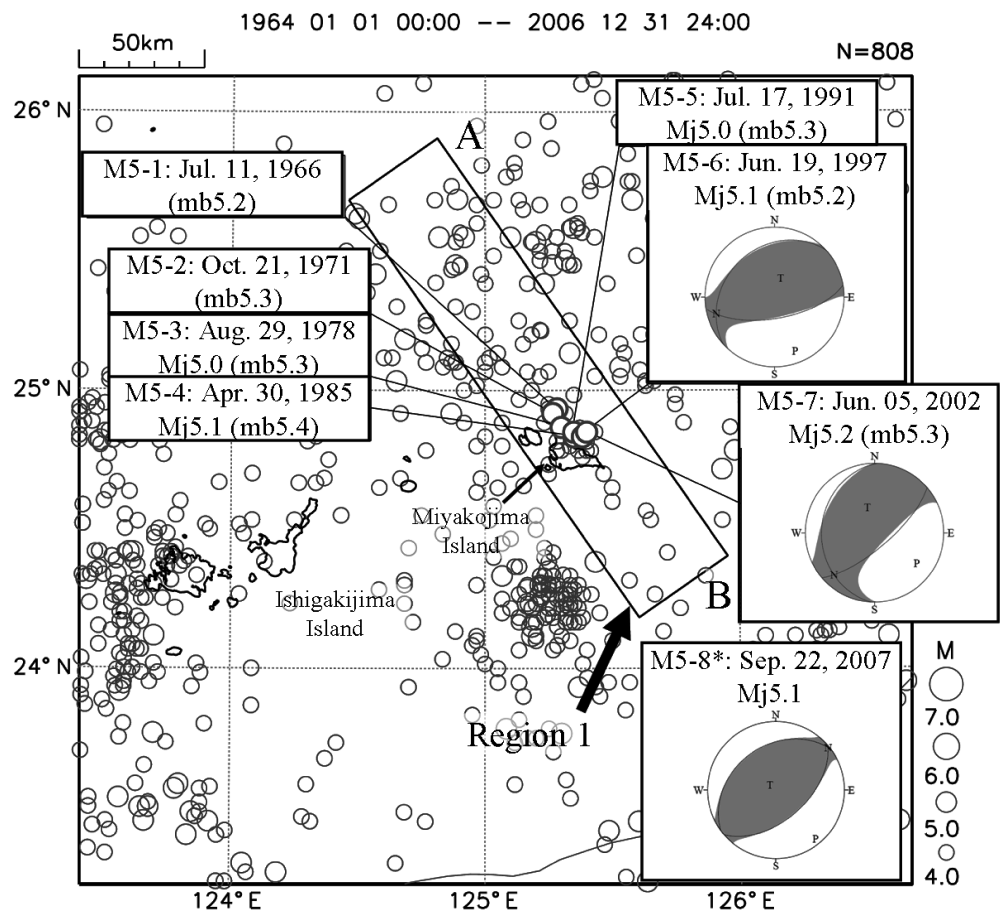

(a)

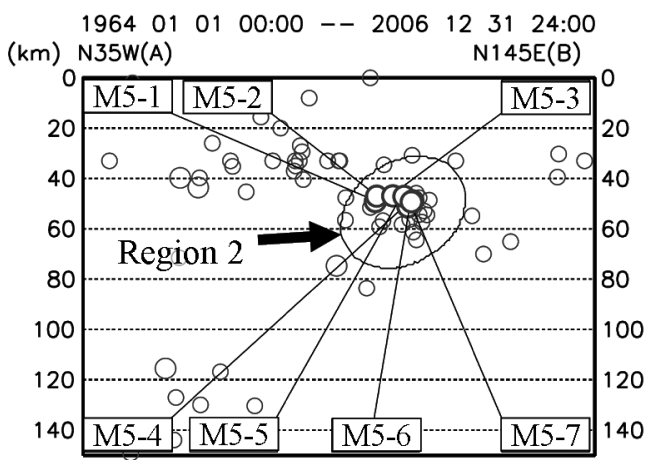

(b)

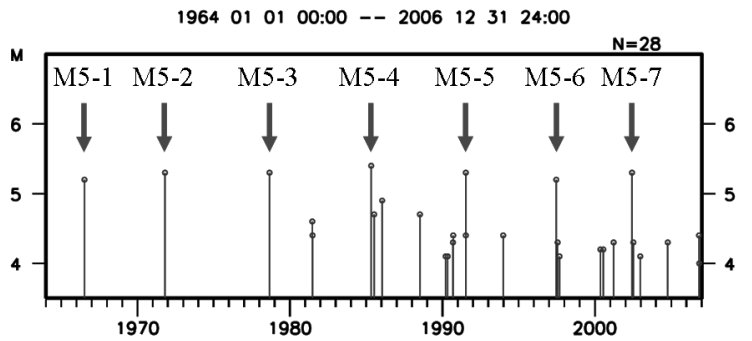

(c)

Fig. 3. Seismic activity near Miyakojima Island (by ISC). (a) Epicenter map from 1964 to 2006. (b) Cross section of the region 1. (c) M-T diagram of the region 2. Centroid moment tensor solutions are determined by the Global CMT Project. *: $M 5-8$ event is outside of the period. 
コヒーレンス值が 0.95 以上であることをグループ化の 条件とした。 なお，相似性が確認された地震の周囲で発 生した地震については，マグニチュードや深さの決定精 度の悪さによって調査漏れとならないように，震度分布 や複数のマグニチュード（速度マグニチュードと変位マ グニチュード）を考慮して対象地震を抽出した。また， OKIGUS は 2000 年 7 月, IKEMA は 2002 年 6 月に運 用を開始しているため，それ以降の期間についてのみ調 査対象とした。

第三に，上記手法によって抽出された相似地震のグ ループをさらにさかのぼって確認するために，1990 年 から 2008 年までの M4 以上の地震について, MIYAKJ の 87 型強震計（サンプリング周波数 $50 \mathrm{~Hz}$ ，測定範囲 $0.1 \sim 10 \mathrm{~Hz}$ ） および 95 型震度計（サンプリング周波数 $100 \mathrm{~Hz}$ ，測定範囲 DC $41 \mathrm{~Hz}$ ）の NS 成分の加速度波 形を变位波形に变換し， $0.5 \sim 3 \mathrm{~Hz}$ の帯域で $\mathrm{P}$ 相の 5 秒 前から 40 秒間の相関係数を計算することにより相似性 を評価した，相似地震のグループに分類する際，相関係 数が 0.95 以上であることをグループ化の条件とした. なお，MIYAKJ は 87 型強震計や 95 型震度計が設置さ れているが, 高感度地震計が設置されている MIYKJ2 とは位置が異なる。ここで，コヒーレンスではなく相関 係数を用いているのは，コヒーレンスでは 87 型強震計 と 95 型震度計のセンサーの違いによる影響が大きく, 相似地震として検出できない場合があるためである。ま た, UD 成分ではなく NS 成分を用いているのは, UD 成 分は変位が小さく，ノイズによる影響が大きくなるため である。

本稿ではコヒーレンスおよび相関係数の定義をそれぞ れ (1), (2) 式のように定義した.

$$
\begin{aligned}
& \text { Coh }=\sqrt{C P S / P_{1} P_{2}}, \\
& C C=\sqrt{\mathbf{X}_{1} \cdot \mathbf{X}_{2} /\left|\mathbf{X}_{1} \| \mathbf{X}_{2}\right|},
\end{aligned}
$$

ただし，Coh はコヒーレンス，CPS はクロスパワースペ クトル， $P_{1}, P_{2}$ はそれぞれの波形のパワースペクトル， $C C$ は相関係数, $\mathrm{X}_{1}, \mathrm{X}_{2}$ はそれぞれ波形のデータベクト ルである. 本稿では, 検出したい地震のマグニチュード に応じて試行錯誤的に帯域を選択したので，相関係数と コヒーレンスで計算する帯域が若干異なっている。コ ヒーレンスおよび相関係数を計算する帯域や相似地震之 みなす閾値の選択については，今後検討の余地がある.

\section{§3. 結果}

1964～2006 年までの ISC カタログの震源分布およ び M-T 図等を Fig. 3 に示す。図中の region 2 では, Fig. 3(c) に示すように, $M 5.1 \pm 0.1$ の地震が平均 5.89 年，標準偏差 0.73 年のほぼ一定な間隔で 8 回発生して いることがわかる，なお，気象庁カ夕ログでは，region 2 で 2007 年 9 月 22 日に $M 5.1$ の地震が発生している ため，それも含めている。 それらの波形 (Fig. 4) は非常 によく似ている. 1991 年以降の 4 地震については, 87 型強震計拉よび 95 型震度計のデジタル波形データが現 存していたので，2007 年の地震を対象として波形相関 を求めると, 0.5 $3 \mathrm{~Hz}$ の帯域で 0.91〜0.96 という高い 相関を示した。広帯域波形を用いて計算した CMT 解 (Global CMT 解) が求められている 1997 年, 2002 年, 2007 年の地震は, 北西一南東方向に圧力軸をむつ低角逆 断層型であり (Fig. 3(a)), 発生位置からプレート境界の 地震であると考えられる。したがって, この地震活動は 岩手県釜石沖の場合 [Matsuzawa et al. (2002)] と同様 に，プレート境界の固有地震とみなすことができる， $M$ 5 クラスの固有地震が波形の相似性から見いだされたの は，世界的に見ても非常に珍しい。 また，琉球弧で固有 地震が見いだされたのは今回が初めてである。これらの $M 5.0$ 以上の固有地震をグループ M5 とした.

次に, 1990 年以降の M4 クラスの地震のなかにむ, 相関係数が 0.95 以上，コヒーレンスが 0.97 以上と相似 性が極めて高い地震群が 3 グループあることがわかっ た。これらのグループを本稿ではそれぞれグループ A, B , C と分類する. Table 1 ( $\mathrm{a}, \mathrm{b})$ に抽出した相似地震群 と各グループ内および各グループ間の，波形の相関係数 およびコヒーレンスを示す。ここで，地震 B-1 (1990/ 09/18) については, 地震 B-8 (2007/05/19) との相関係 数が 0.94 と基準 (0.95 以上) に満たないが，グループ B の他の地震との相関係数が $0.96 \sim 0.99$ と高いので，本 稿ではグループ B に含めた. 各グループの防災科学技術 研究所 F-net Projectによって求められた MT 解はいず れも低角逆断層であり，これらの地震群もプレート境界 で発生したと考えられる. 各グループの位置関係につい ては，気象庁カタログの精度ではグループ間の分離がで きないので，次章で議論する，異なるグループ間の波形 のコヒーレンスは $0.60 \sim 0.91$ 程度であり， 3 系統の地震 群はコヒーレンス值（閾值 0.95）によってある程度客観 的に分類できる。 また，Fig. 5 に示すように各グループ の地震群はそれぞれほぼ同じ時間間隔で繰り返し発生し ており，これらの地震群あまた固有地震とみなすことが できる. 各グループの平均発生間隔と標準偏差を Table 2 に示す.

M4 クラスのグループ内のマグニチュードは, 同じグ ループ内でもばらつきが大きい，これは，主に変位マグ ニチュードと速度マグニチュードが混在しているためで ある。島嶼部では，マグニチュード計算に使用する観測 点が内陸に比べて極端に少ないためにマグニチュードの 


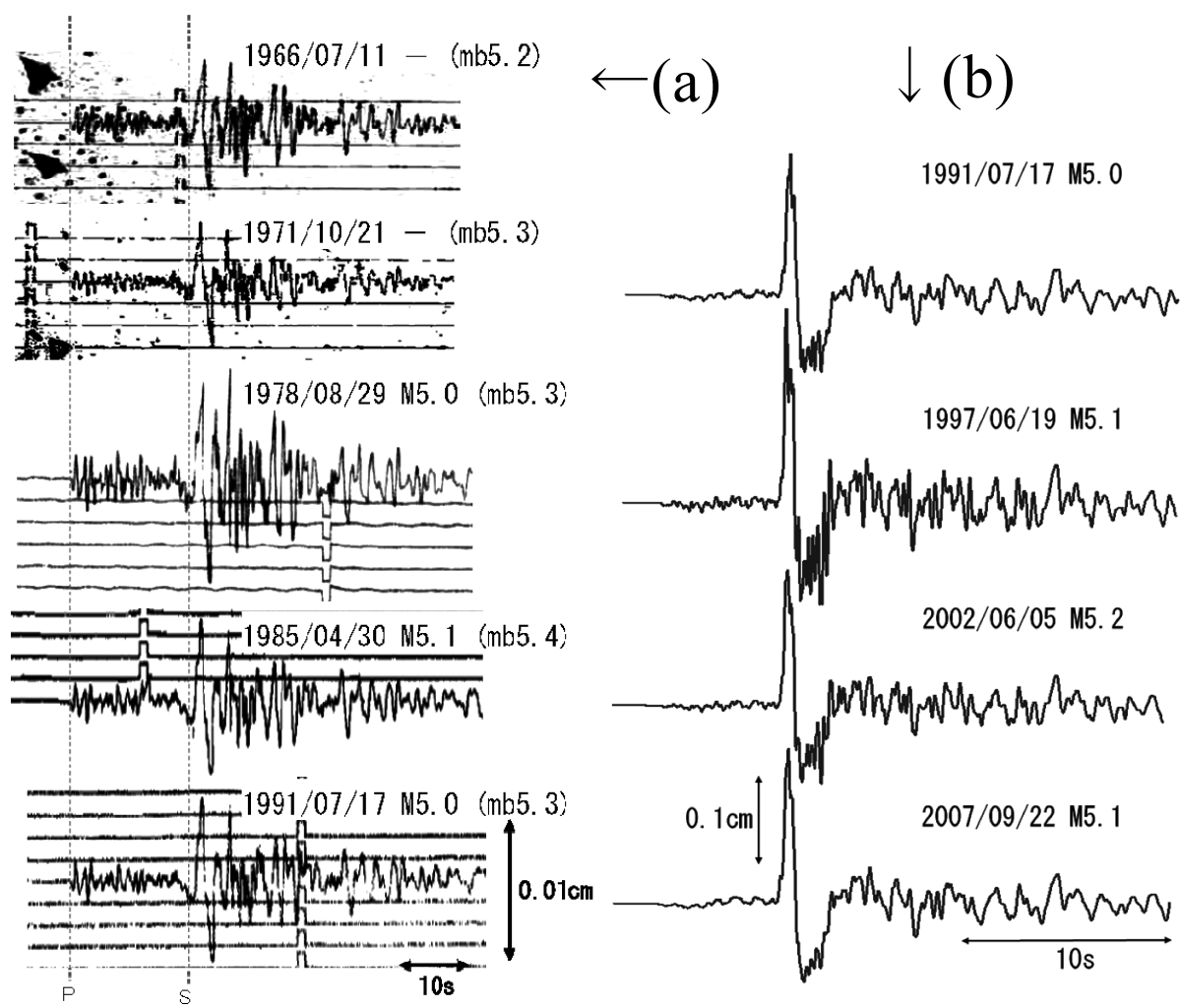

Fig. 4. Records of characteristic earthquakes. (a) Original seismograms (the UD component) by the type 59 seismograph at ISHIGA station. (b) Converted records (the EW component) in the same response from data of type 87 and type 95 seismographs at MIYAKJ station.

精度が劣る。したがって本稿の議論では, $M 5$ クラスの イベントは変位マグニチュード, M 4 クラスのイベント は速度マグニチュードに統一することで，マグニチュー ドのばらつきを小さくすることとする.

\section{§4. 議論}

本解析領域の地震活動は, 大まかに分類すると, 30 $\mathrm{km}$ 以浅では地殼内地震, 深さ $40 \sim 60 \mathrm{~km}$ 程度ではプ レート境界地震, および沈み込むフィリピン海プレート 内の地震と分類される. グループ $M 5$ と $M 4$ クラスの 固有地震群は，それぞれプレート境界上に存在するアス ペリティに, プレートの沈み込みに伴って歪が蓄積し, 繰り返し破壊されることによるあのであると解釈でき る. また,これらの地震群はいずれも深さ $50 \mathrm{~km}$ 程度で あり, 防災科学技術研究所 F-net Projectによって求め られた MT 解の分布 (Fig. 2(b)) から, 琉球弧に打けるプ レート境界型地震が発生する深さとしては下端に位置し ていると考えられる。なお, 琉球弧の他の地域では, プ レート境界の下端ではない場所でも固有地震活動が見つ かっていることを付記しておく［溜㴊・他 (2009)].
波形の特徴に着目すると, Fig. 4(b) に示す波形の中に は, 例えば 1997 年のように短周期成分に富む屯の之, 2007 年のように短周期成分に富まないものがある. 観 測点配置の制約から, 震源過程解析を行うことはできな いが，例えば Uchida et al. (2007)のようにアスペリ ティが階層構造をしているなど，少なくとも全く同一の 破壊過程を繰り返しているものではないと推察される.

M4 クラスの固有地震群の発生時期に着目すると, グ ループ B と C は比較的安定した時間間隔で発生してお り, 標準偏差を平均発生間隔で除した変動係数は $0.12-$ 0.15 とグループ M5 と同程度である. 一方, グループ A の発生間隔は 1.20 年から 3.57 年とばらついており, 変 動係数は 0.30 と他のグループに比べて大きい. ただし, このグループ A のばらつきは, 1990〜1997 年の地震の 発生間隔がばらついていることによるもので, 2000 年 以降の活動だけを見ると安定した時間間隔で発生してい る. 1990 年代にグループ A の発生間隔が乱れたにもか かわらず, 近接するグループ B や C の発生間隔が乱さ れなかった原因はわからない。

なお，固有地震の定義が「ほぼ同じ繰り返し間隔」で 
溜㴊功史・山田安之・石垣祐三・高木康伸・ 中村雅基・前田憲二・岡田正実

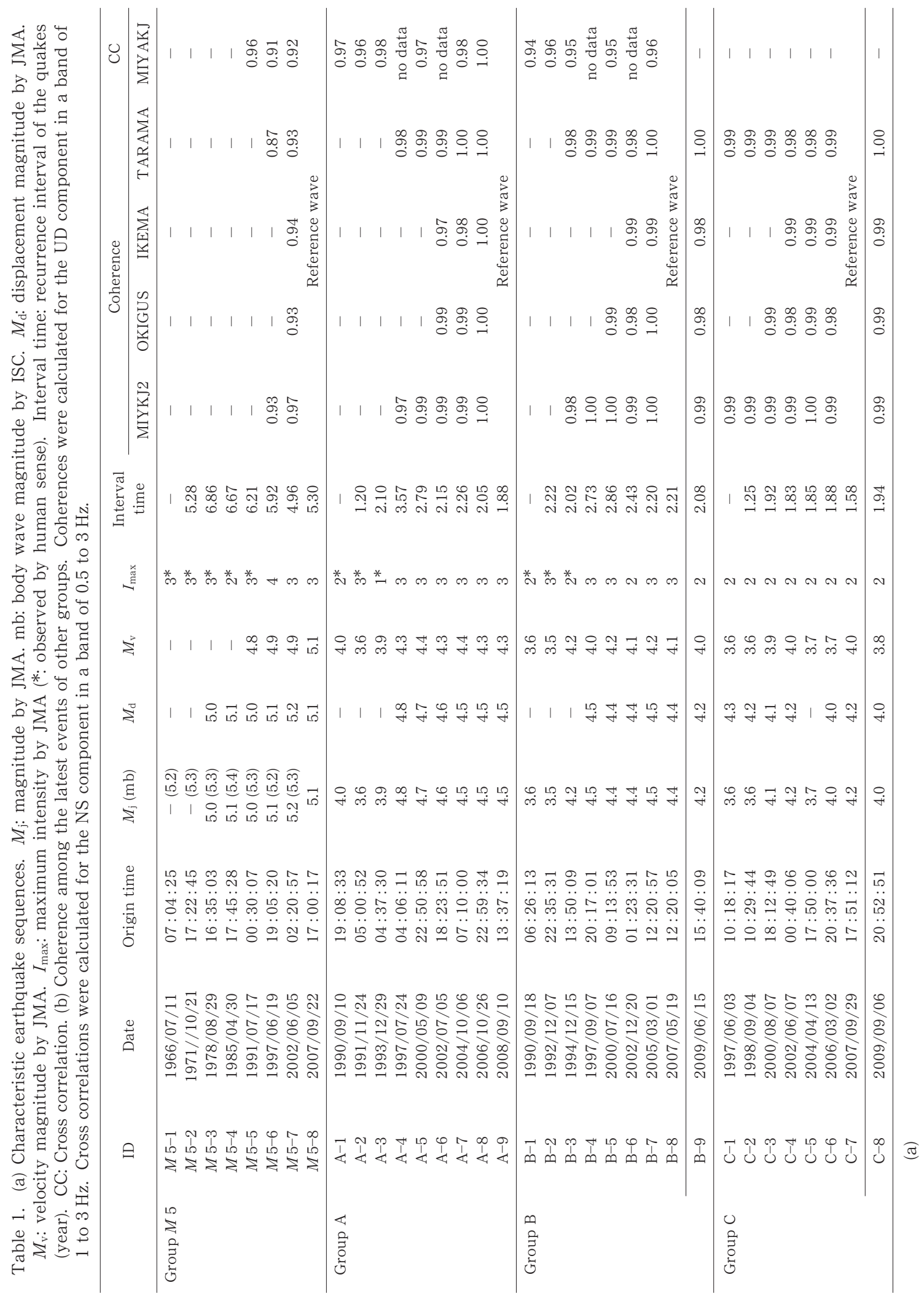



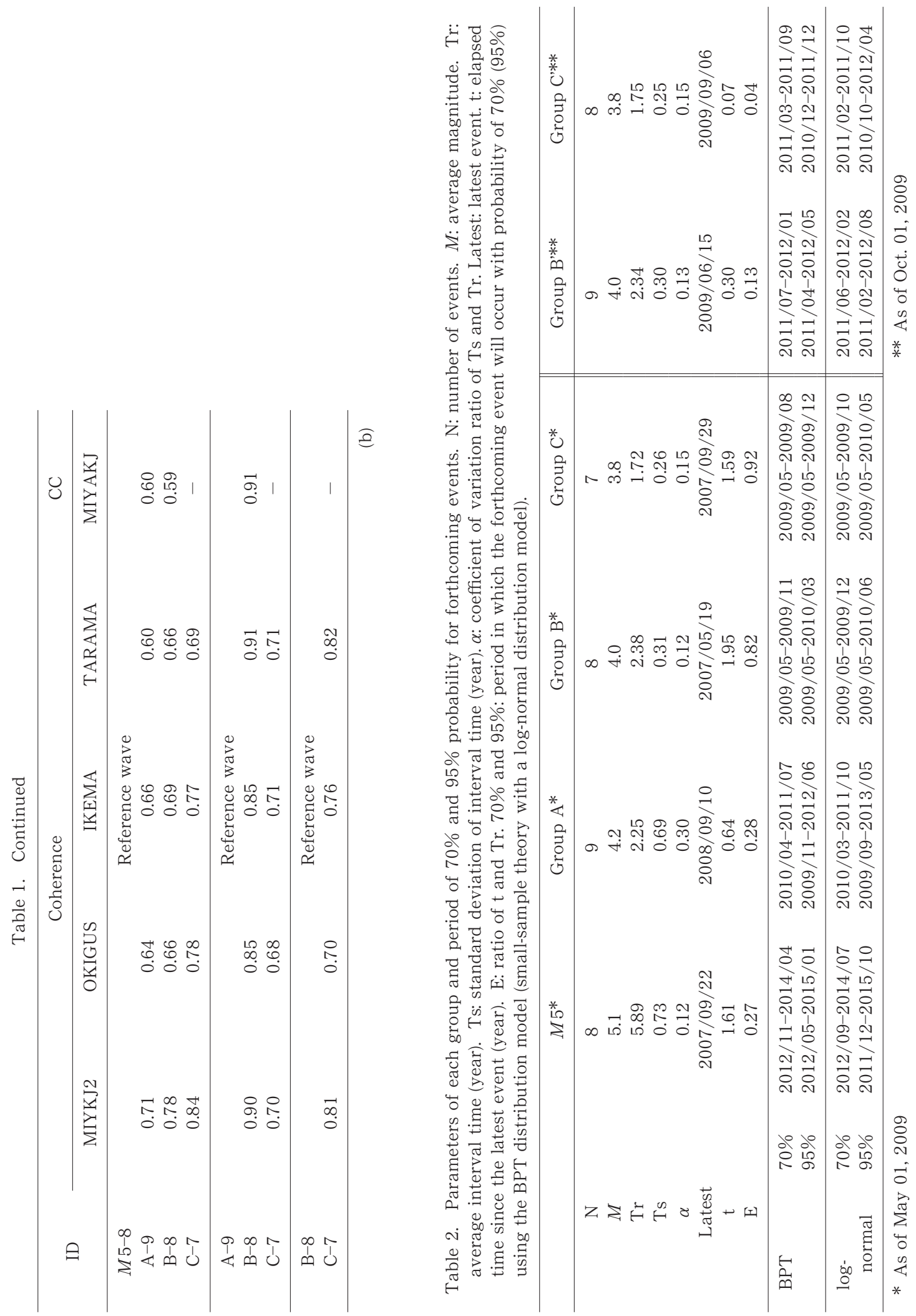


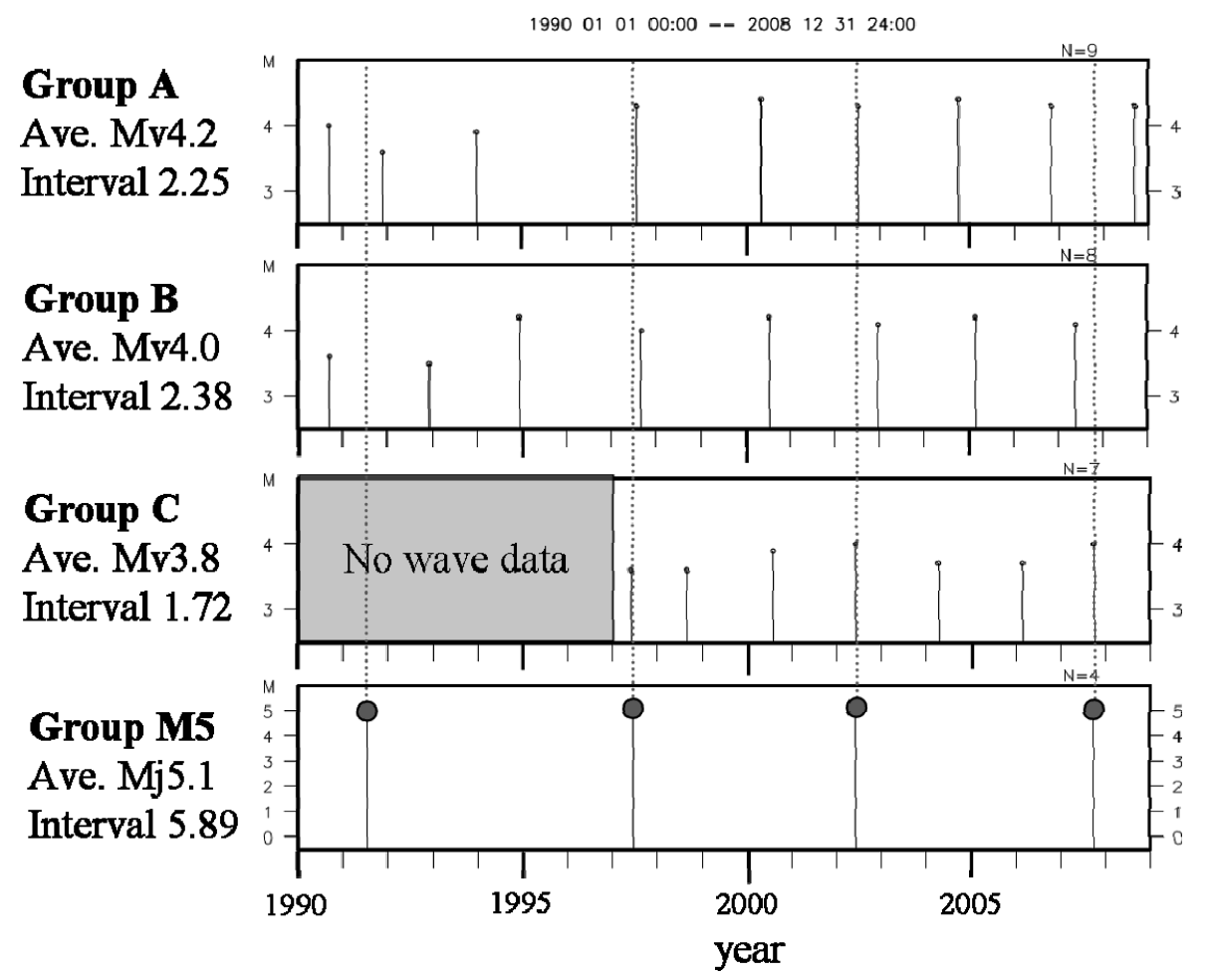

Fig. 5. M-T diagrams of events for four groups since 1990.

あることを第一義に考慮すれば，発生間隔がばらついて いるグループ A は固有地震ではなく, 繰り返し地震と するほうが適当かもしれない, 一方で, 地震調查研究推 進本部は，固有地震モデルを用いて千島海溝沿いの長期 的な地震活動を評価する際, 地震発生間隔の变動係数を 0.24 0.32 としており [地震調査推進研究本部地震調査 委員会 (2004)], 固有地震を発生間隔のばらつきだけか ら定量的に定義することは難しい. また, グループ C は グループ M 5 の前震あるいは余震のように発生してい る場合があるが, 变動係数は 0.15 と小さく, 安定した時 間間隔で発生している.このため, 便宜上本稿ではまと めて固有地震群と総称する.

グループ A と B はそれぞれ独立なアスペリティが固 有の周期で発生しているようにも，相互に影響を及ぼし 合いながら発生しているようにも見える. 例えば, 1990 年以降, グループ B は A が発生した 1 年以内に発生し ている.これはグループ A のアスペリティの破壊が B のアスペリティの破壊を誘発した可能性を示している.

一方で, グループ A と B の地震群はほぼ同じ発生間隔 であるために，全く影響を及ぼし合っていないにもかか わらずそのように見えるだけかむしれない，現時点では サンプル数が少ないので，アスペリティが独立に破壊さ
れているか否かを客観的に議論することはできない.

グループC は 2002 年 6 月 7 日と 2007 年 9 月 29 日 の 2 回, グループ M 5 の発生から 1 週間以内に発生し ている。一方, 1997 年 6 月 3 日のイベントではグルー プCが発生した 16 日後にM 5.1 の地震が発生してい る.このように, グループ $M 5$ とグループ C の地震はか なり連動性がある. したがって, グループCの地震をモ ニタすることで, グループ M 5 の経過率が 1 に近いとき (いわゆる「満期」に近いとき), グループ M5 の発生を 直前に予測できる場合があることを示唆している。な お，波形記録が残っていないため相似性の確認はできな いが，1991年 7 月 17 日に発生した $M 5.0$ の地震の 20 時間前の 7 月 16 日に, 近傍で $M 3.4$ (最大震度 2) の地 震が発生して扣り,これがグループ C に属する地震だっ たのかむしれない.

4 系統の固有地震群の近傍の地震について $b$ 值の計算 を行った. OKIGUS 観測点の運用開始により観測網が 充実し, この付近の震源決定精度が安定した 2000 年 7 月から 2008 年までの深さ $40 \mathrm{~km}$ から $60 \mathrm{~km}$ の震源を 気象庁カタログから抽出した. 本稿では Fig. 6(a) に示 すように, グループ M 5 および $\mathrm{A} \sim \mathrm{C}$ の固有地震が発生 しているアスペリティ周辺と, 比較のために定常的に 


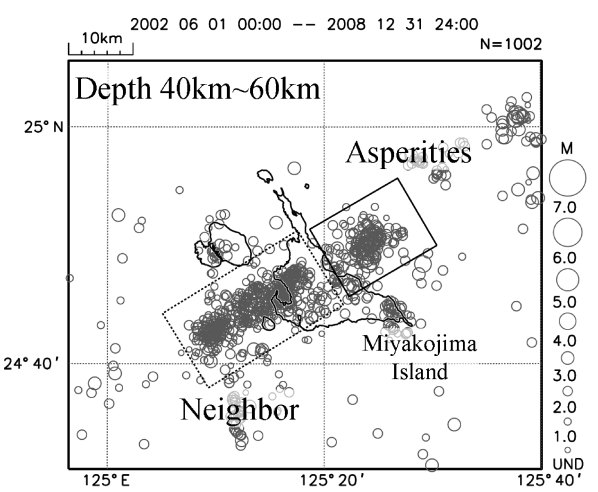

(a)

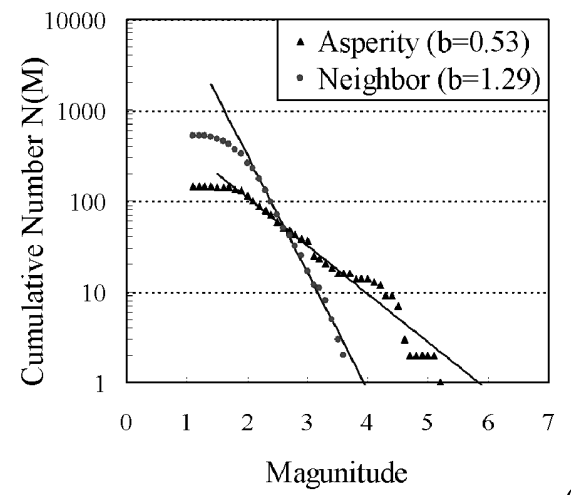

(b)

Fig. 6. Comparison of magnitude-frequency relation between the region including asperities and the neighbor region.

$M 2 \sim 3$ クラスの地震が発生している近接した領域に分 けて $b$ 值を計算した．該当する領域の範囲内にあるすべ ての地震を使用しているので，プレート境界型ではない あのも含まれている. $b$ 值の計算結果を Fig. 6(b) に示す が，大局的に見てアスペリティ周辺の $b$ 值が低いことが わかる。これは，これまで報告されてきたアスペリティ の特徵 [例えば, Wiemer and Wyss (2002)］と矛盾し ない. 一方, Gutenberg-Richterの式に従わないという 固有地震の性質ははっきりとしない.

それぞれの固有地震群の積算すべり量 $(d)$ を推定し た. 手法は Uchida et al. (2003) と同様に, モーメントマ グニチュード $\left(M_{\mathrm{w}}\right)$ と地震モーメント $\left(M_{0}\right)$ の Hanks and Kanamori (1979) による関係式

$$
\log \left(M_{0}\right)=1.5 M_{\mathrm{w}}+16.1
$$

および，地震モーメントとすべり量の関係式 [Nadeau and Johnson (1998)]

$$
\log (d)=-2.36+0.17 \log \left(M_{0}\right)
$$

を用いた。ここで， $M_{\mathrm{w}}$ はモーメントマグニチュードで

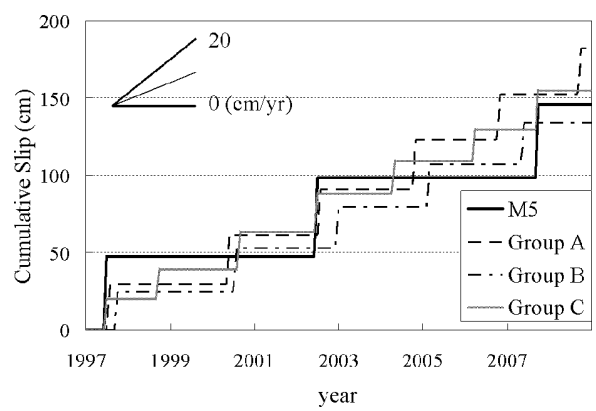

Fig. 7. Cumulative slips of each group since 1997.

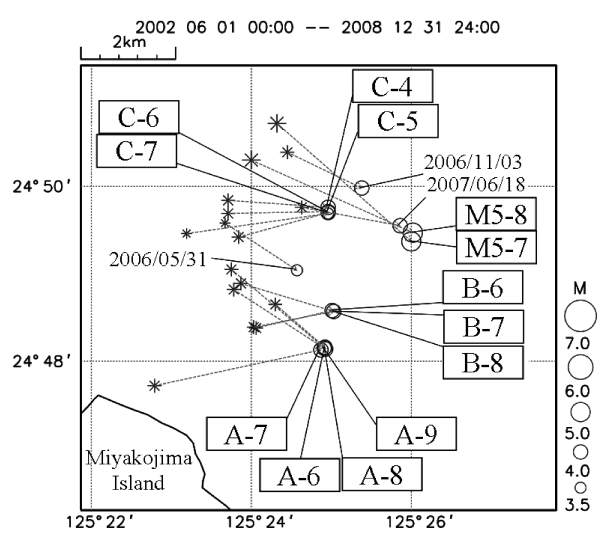

Fig. 8. Relocation of hypocenters using Double-Difference method. Asterisk: JMA catalog hypocenters. Circle: relocated hypocenters.

あるが，気象庁マグニチュード $(M)$ を代用した，グルー プ C の地震群が検知されている 1997 年以降の結果を Fig. 7 に示す. グループ $M 5$ は変位マグニチュード, グ ループ A〜C は速度マグニチュードを使用しているの で, マグニチュードにギャップが生じている可能性はあ るあのの, 積算すべり量はすべてのグループでお㧤むね 一致している. 積算すべり量から得られる年間平均すべ り量は 9 13 cm/yearであり, 琉球弧でのプレート間 の相対速度 (約 $12.5 \mathrm{~cm} /$ year [Heki and Kataoka (2008)]）とあ打执称一致する。したがって，これらの 地震群は異なるアスペリティの破壊によって発生してい るという解釉と矛盾は生じない。 また，これらのアスペ リティのひずみは，打打む权プレートの沈み込みによっ てのみ蓄積されていると考えられる。 さらに，1997年 以降これまで一度も別々のグループに属する地震が同時 には発生していないことも確認できる.

手動で検測している気象庁カタログでは精度に限界が 
あるので, これらのアスペリティの位置をより正確に把 握するために, IKEMA が運用開始となった 2002 年 6 月から 2008 年 12 月までの深さ $40 \sim 60 \mathrm{~km}$ の地震 $(M$ すべて) について, Double-Difference 法 [Waldhauser and Ellsworth (2000)] 用いて震源の再決定を行った. な拝，ここでいうアスペリティとは，地震波エネルギー を最あ放出した点であることを付記しておく，走時差を 計算する際には, MIYKJ 2, OKIGUS, IKEMA, TARAMA の 4 観測点の高感度地震波形 (UD 成分) を 用いて, 手動検測した $\mathrm{P}$ 相, $\mathrm{S}$ 相それぞれの 0.5 秒前か ら 5 秒間のコヒーレンスを $1 \sim 3 \mathrm{~Hz}$ の帯域で計算し, 最むコヒーレンスが大きくなった時刻をDoubleDifferenceのデー夕とした。この際, コヒーレンスの䦨 值は 0.8 とし, 震源計算にはコヒーレンスの 2 乗で重み づけした最小 2 乗法を用いた. Fig. 8 に $M 3.5$ 以上の再 計算結果を示す。これらの四つのアスペリティは $5 \mathrm{~km}$ 程度の範囲内に存在しており, 同じグループの地震はほ ぼ同じ場所に求められている. グループ C が最むグルー プM 5 に近く, 前述のと抢りグループ M 5 に連動しや すいとした推定を支持する. また, グループ A と B の距 離む $1 \mathrm{~km}$ 程度で, 抒いに影響を及ぼし合っている可 能性があることとも矛盾しない。

(3) 式と, 地震モーメントとアスペリティの大きさ $(A)$ の関係式 [Nadeau and Johnson (1998)]

$\log (A)=-9.12+0.83 \log \left(M_{0}\right)$

を用いると，アスペリティの大きさは， $M 5.1$ で $4 \mathrm{~km}^{2}$ 程度, $M 4$ クラスで $0.1 \sim 1 \mathrm{~km}^{2}$ 程度である. したがっ て，これらのアスペリティが円であると仮定したときの 半径 (等価半径) は, $M 5.1$ で $1 \mathrm{~km}$ 程度, $M 4$ クラスで $0.2 \sim 0.5 \mathrm{~km}$ 程度であり, DD 法を用いて再計算した震 源間距離と比較しても, 異なるグループの地震が異なる アスペリティであり, かつ同じグループの地震が同じア スペリティ内で発生していることが確認できる.

ただし, 波形の相互相関から走時差を求める手法は, 本来, $\mathrm{P}$ 波, $\mathrm{S}$ 波の初動を正確に合わせるための手法で あり, 短いサンプルで $10 \mathrm{~Hz}$ 程度の高周波域を対象にす るのが一般的である. 本稿のように $1 \sim 3 \mathrm{~Hz}$ の帯域を適 用するのは, 同じ場所, 同じ破壊過程の地震同士のアス ペリティを比較する場合には適切であると言えるが, 少 しでも場所が違い，破壊過程む違うと思われる地震間の アスペリティを比較する場合には不適切である可能性す 否定できない. Double-Difference 法の計算で必要とさ れる走時差は “震源（破壊開始点）間の距離を反映した 走時差”であり, 本稿の計算で使われた走時差は “アス ペリティ間の距離+破壊過程の位相の違いを反映した走 時差”であることに留意しなければならない。したがっ

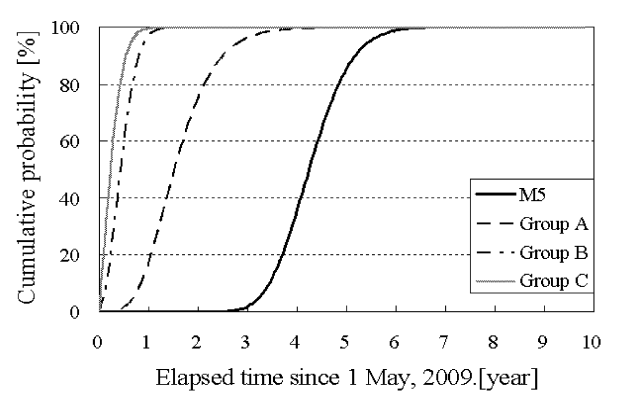

(a)

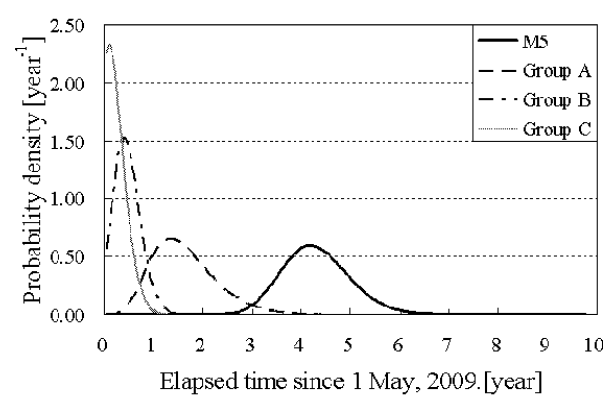

(b)

Fig. 9. (a) Cumulative probability and (b) probability density for occurrence of the next earthquakes using the small-sample theory with a log-normal distribution model.

て, 同じグループ内の相対的な位置関係は再現できるも のの, 他のグループ間の相対的な位置関係は十分再現で きていない可能性が考えられる. 卓越周期も異なるグ ループ間の相対的なアスペリティの位置を高精度に求め ることは今後の課題である.

$M 5$ クラスの固有地震の近傍で, 一回り小さい M 4 ク ラスの相似地震を複数のグループに分類することができ た. 同様の事例は, 岩手県釜石沖でも知られている [Uchida et al. (2007)]. しかし, 本稿の事例では, これら のひと回り小さい地震む, 連動性がある場合があるあの の発生間隔やマグニチュードがほぼ一定な固有地震活動 をして抢り，この点が岩手県釜石沖の事例と異なる。ま た, これらの地震活動の特徵の一つに余震の少なさがあ る. 過去に観測されたグループ M 5 の余震はグループ C の地震以外はほとんどない。したがって, 周囲に連動し て破壊されるような小アスペリティはほとんどなく,こ れらのアスペリティは安定したすべり域の中に存在して いると考えられる.

琉球弧では $M 7$ を超えるようなプレート境界の地震 は知られておらず, 応力場を乱したり, プレートの定常 的な沈み込み以外にアスペリティにひずみを蓄積したり 
するイベントが少ない，したがって，この付近全体のプ レート間のカップリングは弱いが，何らかの理由による 部分的な固着がいくつかあり，それらのうちの大きなむ のが四つの固有地震群が発生するアスペリティに対応し ていると解釈できる.このことは, 琉球弧のほかの領域 でも，固有地震活動が存在することを示唆している．実 際, 沖永良部島近海や沖縄本島近海などで $M 5$ から $M 4$ クラスの固有地震活動がいくつか報告されている[溜 㴊・他 (2009)]。 また，他のイベントの影響が少ないと いうことは, 数值シミュレーションや物理過程を検証す るうえで単純化しやすいので，研究の対象としやすい利 点になる.

過去の発生間隔から，それぞれの固有地震群につい て, 次の地震の発生確率を計算した。 その際, 地震調查 研究推進本部で地震発生の長期評価を行う際に用いてい る更新過程 $\mathrm{BPT}$ 分布モデル [地震調査研究推進本部地 震調査委員会 $(2001)$ ） と，更新過程小標本論対数正規分 布モデル [例えば，岡田 (2009)］を用いた. 各グループ の発生確率を Table 2 に, 更新過程小標本論対数正規分 布モデルの累積確率および確率密度関数を Fig. 9 に示 す. 7 個から 9 個の少ない地震数から適切に発生確率を 計算する必要があるため, パラメー夕の推定䛊差を考慮 している更新過程小標本論対数正規分布モデルを用いる ほうが適切であると考えられる，そこで，更新過程小標 本論対数正規分布モデルの解析結果で議論を進める. 次 のグループ M 5 の固有地震は, 基準日を 2009 年 5 月 1 日として，2012 年 9 月から 2014 年 7 月までの間に $70 \%$ の確率で発生すると考えられる。同様にグループ A は， 2010 年 3 月から 2011 年 10 月までの間に $70 \%$ の確率で発生すると考えられる。また，2009 年 12 月ま でにグループ B と C の固有地震が発生するのは，それ ぞれ 70\%,85\% 程度となっている。なお，ここで示した 確率は, 個々のグループの発生間隔のみから統計的に求 めたものであることに留意しなければならない.

過去の地震発生状況を踏まえると, グループ M5 の固 有地震発生から数日以内にグループ Cのアスペリティ を破壊する可能性がある。また，まだ 1 例しかないため よくわかっていないが，グループ M5 の経過率が 1 に近 いときにグループ C が発生した場合，グループ M 5 が 誘発されるかもしれない。 さらに，グループ B の地震が $\mathrm{A}$ の地震発生の 1 年以内に発生していることを考慮す れば，グループ B が 2009 年 9 月までに発生する可能性 は，個々のグループの発生間隔のみから求めた確率より は高くなるだろう。実際，本稿執筆中の 2009 年 6 月 15 日 15 時 40 分に宮古島近海で M 4.2 の地震が発生し, 宮古島で最大震度 2 を観測した。この地震は, グループ
B に属する地震とのコヒーレンス值が $0.98 \sim 1.00$ と極 めて高く，グループ B に分類できる (Table 1). 前回の 地震からの経過時間は 2.08 年で, いずれの分布モデル の場合でも Table 2 に予測した $70 \%$ 信頼区間の範囲内 で発生している. また, 今回の地震もグループ A の地震 発生から 1 年以内に発生したことは興味深い.さらに, 本稿査読中の 2009 年 9 月 6 日 20 時 52 分にも宮古島 でM4.0 の地震が発生し, 宮古島で最大震度 2 を観測し た。この地震は, グループ C に属する地震とのコヒーレ ンス值が $0.99 \sim 1.00$ と極めて高く，グループ C に分類 できる (Table 1). 前回の地震からの経過時間は 1.94 年 で，小標本論対数正規分布モデルの場合で Table 2 に予 測した $70 \%$ の信頼区間内で発生した。グループ B, C の 地震が次に発生すると予測される期間を Table 2 にグ ループ B', $\mathrm{C}^{\prime}$ として示す (基準日：2009 年 10 月 1 日).

この領域で M 5.1 程度の地震が発生した場合, 過去に は宮古島で最大震度 $4 \sim 3$ を, M 4 クラスのうちグルー プ $\mathrm{A}$ は最大震度 3, グループ $\mathrm{B}$ は最大震度 $3 \sim 2, \quad$ グ ループ C は最大震度 2 をそれぞれ観測している，特に 1997 年 6 月 19 日に発生した $M 5.1$ の地震では, 宮古 島で最大震度 4 を観測し, およそ 1 万世帯で一時停電が 発生した。これらの地震の発生を事前に予測しておくこ とは，学問的にだけでなく防災上む有意義なことであ る.

\section{§5. まと め}

1966 年以降，宮古島近海の深さ $50 \mathrm{~km}$ 付近で $M 5.1$ 程度の地震が平均 5.89 年, 標準偏差 0.73 年の間隔で周 期的に 8 回発生している固有地震が見つかった.

この周辺における 1990 年以降の $M 4$ 程度以上の地震 について波形の相似性が極めて高いグループが三つに分 類でき，それぞれの地震群もまた固有地震であるとみな せる. M5 超える固有地震が波形の相似性から見いだ されたのは，世界的に見て屯珍しく，琉球弧における固 有地震調査のきっかけとなった。 また，M5クラスの固 有地震の近傍にありながらも同時に破壊されることなく M4 クラスの固有地震が発生していることは, 宮古島近 海における固有地震活動の大きな特徴である.

宮古島近海の狭い領域で, M5 クラスの地震を含めて 4 グループの固有地震活動が見られるのは, 琉球弧では 発生周期を乱すようなイベントが少ないことが要因であ ると考えられる.したがって, 琉球弧のほかの領域でも, 固有地震活動が見られると考えられる. また，他のイべ ントの影響が少ないので，地震の発生過程を理解するう えで最む単純化して考えることができ，学問的に興味深 い領域の一つである. 
宮古島近海の深さ約 $50 \mathrm{~km}$ のプレート境界で発生す る次の $M 5$ クラスの地震は, 基準日を 2009 年 5 月 1 日 として，更新過程小標本論対数正規分布モデルを仮定す ると, 2012 年 9 月から 2014 年 7 月までの間に $70 \%$ の 確率で発生すると考えられる. また, 過去の地震発生状 況を踏まえると, 本震発生から数日以内に, $M 4$ 程度の グループCのアスペリティの破壊を誘発する可能性が ある。

\section{謝辞}

本稿を執筆するに当たって, 東京大学地震研究所の酒 井慎一准教授と 1 名の匿名査読者, および編集委員の産 業技術総合研究所の今西和俊博士から種々のご指摘をい ただき, 改稿にたいへん役立ちました. 琉球大学の中村 衛博士には有益な助言を多くいただきました。記録の収 集では, 沖縄気象台, 宮古島地方気象台および石垣島地 方気象台の協力をいただきました，また，ハーバード大 学などの Global CMT Projectによって求められたメカ ニズム解析結果 (Global CMT 解), 防災科学技術研究 所 F-net Projectによる広帯域地震波形を用いたメカ二 ズム解析結果 (MT 解), および ISC (国際地震セン ター）によって決定された震源カタログを使用しまし た，図の作成拧よび $b$ 值の計算には, 横山 (1997) による 震源表示プログラム, おょびREASA [明田川・他 (2007)］を利用しました。 これらの方々および関係機関 に感謝いたします。

\section{文献}

明田川 保・伊藤秀美・弘瀬冬樹, 2007, X Windows System を用いた地震検索・地震活動解析プログラム (REASA) の開発, 験震時報, 70, 51-66.

Chen, K.H., R. M. Nadeau, and R.-J. Rau, 2007, Toward a universal rule on the recurrence interval scaling of repeating earthquakes?, Geophys. Res. Lett., 34, doi: 10.1029/2007GL030554.

Hanks, T. C. and H. Kanamori, 1979, A moment magnitude scale, J. Geophys. Res., 84, 2348-2350.

長谷川安秀 - 橋本徹夫 - 草野富二雄 - 吉川一光 - 大西星 司, 2005, 東北地方における中規模地震の固有地震的 地震活動の検出, 地震 $2,58,67-70$.

Heki, K. and T. Kataoka, 2008, On the biannually repeating slow-slip events at the Ryukyu Trench, Southwestern Japan, J. Geophys. Res., 113, doi: 10.1029/2008JB005739.

五十嵐敏博, 2002, 三陸沖の固有地震的地震活動, なる ふる, 31, 2-3.

Igarashi, T., T. Matsuzawa, and A. Hasegawa, 2003, Repeating earthquakes and interplate aseismic slip in the northeastern Japan subduction zone, J. Geophys. Res., 108(B5), 2249, doi: 10.1029/2002JB
001920.

地震調査研究推進本部地震調査委員会, 2001, 長期的な 地震発生確率の評価手法について, 99 pp.

地震調査研究推進本部地震調査委員会, 2004, 千島海溝 沿いの地震活動の長期評価（第二版）について，地震 調査委員会報告集一 2004 年 1 月～12 月一, II-919II-1025.

Matsubara, M., Y. Yagi, and K. Obara, 2005, Plate boundary slip associated with the 2003 Off-Tokachi earthquake based on small repeating earthquake data, Geophys. Res. Lett., 32, doi: 10.1029/ 2004 GL022310.

Matsuzawa, T., T. Igarashi, and A. Hasegawa, 2002, Characteristic small-earthquake sequence off Sanriku, northeastern Honshu, Japan, Geophys. Res. Lett., 29(11), 1543, doi: 10.1029/2001GL014632.

Nadeau, R. M. and L. R. Johnson, 1998, Seismological studies at Parkfield VI: Moment release rates and estimates of source parameters for small repeating earthquakes, Bull. Seism. Soc. Am., 88, 790-814.

岡田正実, 2009, 繰り返し地震および余震の確率予測, 地震 2, 61, 特集号, S143-S153.

Schaff, D. P. and G. C. Beroza, 2004, Coseismic and postseismic velocity changes measured by repeating earthquakes, J. Geophys. Res., 109, doi: 10.1029/2004JB003011.

Schwartz, D. P. and K. J. Coppersmith, 1984, Fault behavior and characteristic earthquakes: examples from the Wasatch and San Andreas fault zones, J. Geophys. Res., 89, 5681-5698.

Seno, T., S. Stein, and A. E. Gripp, 1993, A model for the motion of the Philippine Sea plate consistent with NUVEL-1 and geological data, J. Geophys. Res., 98, 17941-17948.

Shimazaki, K. and T. Nakata, 1980, Time-predictable recurrence model for large earthquakes, Geophys. Res. Lett., 7, 279-282.

溜㴊功史, 山田安之, 石垣祐三, 高木康伸, 中村雅基, 前田憲二, 岡田正実, 2009, 琉球弧で見つかったいく つかの固有地震的地震活動, 日本地球惑星科学連合大 会予稿集, S149-P005.

Uchida, N., T. Matsuzawa, T. Igarashi, and A. Hasegawa, 2003, Interplate quasi-static slip off Sanriku, NE Japan, estimated from repeating earthquakes, Geophys. Res. Lett., 30, doi: 10.1029/2003GL 017452 .

Uchida, N., A. Hasegawa, T. Matsuzawa, and T. Igarashi, 2004, Pre- and post-seismic slow slip on the plate boundary off Sanriku, NE Japan associated with three interpolate earthquakes as estimated from small repeating earthquake data, Tectonophysics, 385, 1-15.

Uchida, N., T. Matsuzawa, A. Hasegawa, and T. Igarashi, 2005, Recurrence intervals of characteristic $M$ $4.8 \pm 0.1$ earthquakes off-Kamaishi, NE JapanComparison with creep rate estimated from small repeating earthquake data, Earth Planet. Sci. Lett., 
233, 155-165.

Uchida, N., T. Matsuzawa, W. L. Ellsworth, K. Imanishi, T. Okada, and A. Hasegawa, 2007, Source parameters of a $M 4.8$ and its accompanying repeating earthquakes off Kamaishi, NE Japan: Implications for the hierarchical structure of asperities and earthquake cycle, Geophys. Res. Lett., 34, doi: 10.1029/2007GL031263.

Waldhauser, F. and W. L. Ellsworth, 2000, A doubledifference earthquake location algorithm: Method and application to the Northern Hayward Fault,
California, Bull. Seism. Soc. Am., 90, 1353-1368.

Wiemer, S. and M. Wyss, 2002, Mapping spatial variability of the frequency magnitude distribution of earthquakes, Adv. Geophys., 45, 259-302.

Yamawaki, T., T. Nishimura, and H. Hamaguchi, 2004, Temporal change of seismic structure around Iwate volcano inferred from waveform correlation analysis of similar earthquakes, Geophys. Res. Lett., 31, doi: 10.1029/2004GL021103.

横山博文, 1997, X ウィンドウシステムを用いた地震活 動解析プログラム, 験震時報, $60,37-51$. 